\title{
Kemandirian Belajar Mahasiswa dalam Pembelajaran Jarak Jauh Selama Masa Pandemi
}

\author{
Alberta Parinters Makur1, Emilianus Jehadus ${ }^{2 *}$, Sebastianus Fedi ${ }^{3}$, Silfanus Jelatu ${ }^{4}$, \\ Viviana Murni ${ }^{5}$, Polikarpus Raga ${ }^{6}$
}

\author{
1,2*3,4,5,6Program Studi Pendidikan Matematika, Unika Santu Paulus Ruteng \\ Jalan Ahmad Yani no 10, Ruteng, NTT, Indonesia \\ 1alberta_makur@unikastpaulus.ac.id, ${ }^{2 *}$ rebasarong@gmail.com \\ ${ }^{3}$ sebastianus_fedi@unikastpaulus.ac.id, ${ }^{4}$ silfanusjelatu@yahoo.co.id \\ 5vivianamurni0123@gmail.com,6polikarpus_raga@unikastpaulus.ac.id
}

Artikel diterima: 23-09-2020, direvisi: 29-01-2021, diterbitkan: 31-01-2021

\begin{abstract}
Abstrak
Penelitian ini dilakukan untuk melihat kemandirian belajar mahasiswa pada mata kuliah Matematika Dasar dalam mengikuti pembelajaran jarak jauh khususnya pembelajaran dalam jaringan selama masa Pandemi Covid-19. Merupakan penelitian kuantitatif-deskriptif dengan 85 orang mahasiswa tahun pertama Prodi Sosial Ekonomi Pertanian Universitas Katolik Indonesia Santu Paulus Ruteng dengan fokus untuk mempelajari kemandirian belajar mahasiswa yang mengikuti pembelajaran dalam jaringan karena situasi Pandemi Covid-19. Hasil penelitian menunjukkan $18.82 \%$ mahasiswa yang memiliki kemandirian belajar rendah, sedangkan $81.18 \%$ mahasiswa memiliki kemandirian belajar yang tinggi. Selanjutnya, dalam wawancara semi terstruktur ditemukan bahwa mahasiswa pada awalnya mengalami kesulitan dalam beradaptasi perubahan kebiasaan belajar, keterbatasan sumber daya belajar dalam jaringan, dan kurangnya interaksi baik sesama mahasiswa maupun dengan dosen. Keterbatasan ini mendorong mahasiswa semakin mandiri dalam belajar yang terlihat dari lebih dari $70 \%$ mahasiswa sudah menetapkan tujuan belajar, strategi belajar, mampu mengatur waktu belajar, dan melakukan evaluasi diri terhadap proses pembelajaran yang telah diikuti. Lebih dari $80 \%$ mahasiswa menentukan lingkungan belajar yang mendukung suasana belajar dan mencari bantuan dari rekan sekelas apabila mengalami kesulitan dalam belajar.

Kata Kunci: kemandirian belajar, pandemic Covid-19, pembelajaran jarak jauh.
\end{abstract}

\section{Students' Learning Using Long Distance Learning During Pandemic Abstract}

This research was conducted to see the independence of student learning in the Basic Mathematics course in participating in distance learning, especially online learning during the Covid-19 Pandemic. This is a quantitative-descriptive study with 85 first-year students of the Agricultural Socio-Economic Study Program of the Indonesian Catholic University, Santu Paulus Ruteng, with a focus on studying the learning independence of students who take online learning due to the Covid-19 Pandemic situation. The results showed $18.82 \%$ of students had low learning independence, while $81.18 \%$ of students had high learning independence. Furthermore, in semistructured interviews, it was found that students initially experienced difficulties in adapting to changes in learning habits, limited learning resources in the network, and a lack of interaction between students and lecturers. This limitation encourages students to be more independent in learning, which can be seen from more than $70 \%$ of students who have set learning goals, learning strategies, being able to manage study time, and conduct self-evaluation of the learning process that has been followed. More than $80 \%$ of students determine a learning environment that supports a learning atmosphere and seek help from classmates.

Keywords: independent learning, Covid-19 pandemic, distance learning. 


\section{Pendahuluan}

Pandemi Covid-19 di seluruh dunia membawa transformasi pendidikan yang "memaksa" diterapkannya pendidikan jarak jauh (Dilmaç, 2020; Afriansyah, dkk., 2020; Gross \& Opalka, 2020). Dilmaç (2020) menjelaskan semua universitas tidak dipersiapkan untuk pembelajaran jarak jauh sebagai akibat dari Pandemi Covid-19. Lebih lanjut, Gross \& Opalka (2020) menyatakan daerah pedesaan, di mana infrastruktur internet tertinggal jauh di belakang daerah perkotaan dan pinggiran kota, akan menghadapi lebih banyak tantangan dalam menyediakan pembelajaran jarak jauh.

Dilmaç (2020) menyatakakn pembelajaran jarak jauh (distance learning) dilaksanakan di lingkungan di mana pengajar dan siswa terpisah satu sama lain dalam hal waktu dan ruang. Pembelajaran ini bertujuan memberikan memberikan kesempatan kepada individu untuk mendapatkan kesempatan yang dia lewatkan di dunia pendidikan. Selain itu, juga bertujuan untuk menekan biaya pendidikan dan meningkatkan kualitas pendidikan. Pembelajaran jarak jauh ini bertujuan di antaranya untuk mengintegrasikan teknologi dengan pendidikan dan untuk menghilangkan hambatan untuk mengakses informasi, untuk memberikan pendidikan dan pengetahuan berkelanjutan yang sejalan dengan teknologi komunikasi, serta membantu mempertahankan proses pendidikan yang terencana dan sistematis.
Pembelajaran jarak jauh memiliki keterbatasan di antaranya rendahnya partisipasi pembelajar selama proses pembelajaran sehingga diperlukan pemilihan strategi yang sangat selektif untuk mendorong partisipasi belajar dari pembelajar. Beberapa peneliti telah melakukan penelitian untuk melihat faktor-faktor yang mempengaruhi partisipasi pembelajar dan strategi untuk mendorong partisipasi pembelajar tersebut dalam pembelajaran online/ pendidikan jarak jauh (Chyr et al., 2017; Erin \& Maharani, 2018; Tezer et al., 2019; Yilmaz \& Banyard, 2020). Chyr, dkk (2017) secara khusus membahas pengaruh online academic help-seeking (OAHS) and flipped learning ( $\mathrm{FL})$ terhadap perkembangan siswa, efikasi diri, dan kemandirian belajar. Salah satu hasil penelitiannya menunjukkan bahwa keterlibatan siswa, efikasi diri, dan pembelajaran mandiri siswa semuanya meningkat menerapkan OAHS dan FL. Lalu, Tezer, dkk (2019) melakukan penelitian untuk mengetahui pengaruh pembelajaran matematika online secara mandiri dan kolaboratif terhadap prestasi belajar matematika mahasiswa. Hasilnya, mahasiswa mengalami peningkatan yang signifikan dalam keberhasilan mereka dikarenakan adanya praktik mengajar di lingkungan pembelajaran online. Sementara itu, Yilmaz dan Banyard (2020) meneliti studi yang berfokus pada keterlibatan siswa dalam pendidikan jarak jauh menggunakan teknik analisis tren. Analisis menunjukkan 
bahwa ada peningkatan dalam upaya untuk memahami keterlibatan siswa dalam proses pembelajaran jarak jauh ini.

Penelitian ini secara khusus dilakukan untuk mempelajari kemandirian belajar mahasiswa Program Studi Sosial Ekonomi Pertanian di lingkup Universitas Katolik Indonesia (Unika) Santu Paulus Ruteng yang mengikuti pembelajaran dalam jaringan karena situasi Pandemi Covid-19 dengan disertai pendapat mereka terkait pembelajaran dalam jaringan ini. Kemandirian belajar sendiri diartikan sebagai sifat, kemauan, dan kemampuan siswa untuk melakukan kegiatan belajar aktif yang didorong oleh motivasi untuk menguasai sesuatu kompetensi yang tetah ditetapkan (Assagaf, 2017; Foster \& Cresap, 2012; Mulyono, 2017; Pratiwi et al., 2018; Sundayana, 2019; Tezer et al., 2019; Robiana \& Handoko, 2020; Nurhikmayati \& Suhendar, 2020).

Penelitian ini penting untuk dilakukan mengingat pembelajaran jarak jauh merupakan satu-satunya pilihan pembelajaran yang memungkinkan di tengah situasi pandemik ini. Pembelajaran jarak jauh mensyaratkan adanya kemandirian belajar mahasiswa selama proses pembelajaran untuk mengoptimalkan hasil belajar dari mahasiswa. Untuk itu, keterkaitan antara pembelajaran jarak jauh dan kemandirian belajar perlu dikaji lebih lanjut sebagai referensi dari pembelajaran yang telah dilakukan.
Universitas Katolik Indonesia (Unika) Santu Paulus Ruteng yang terletak di Nusa Tenggara Timur mendorong pengajar untuk bersikap fleksibel dan tetap menunjukkan kepedulian kepada mahasiswa dalam proses pembelajaran jarak jauh dengan menggunakan jaringan internet ini. Ini dilakukan mengingat banyak mahasiswa tidak memiliki akses ke komputer dan Internet sebagai syarat utama berlangsungnya pembelajaran jarak jauh.

Penelitian keterkaitan kemandirian belajar dan pembelajaran jarak jauh ini dilakukan untuk menggali pengalaman mahasiswa selama proses pembelajaran yang "bertransformasi drastis" dikarenakan adanya Pandemi Covid-19 secara khusus dalam Mata Kuliah Matematika Dasar TA 2020/2021 di Unika Santu Paulus Ruteng. Aspek-aspek yang dilihat adalah: apa saja kesulitan yang dialami selama proses pembelajaran dalam jaringan karena situasi Pandemi Covid-19 ini, apa saja manfaat atau potensi atau kelebihan dari pembelajaran jarak jauh ke depannya, apa kekurangan dari pembelajaran jarak jauh yang telah diterapkan, dan seberapa memadai infrastruktur teknologi yang dimiliki universitas untuk mengoptimalkan masa transisi pembelajaran dalam jaringan selama masa darurat Pandemi Covid-19.

\section{Metode}

Penelitian ini dilakukan dengan menggunakan pendekatan penelitian 
kuantitatif-deskriptif. Fokus penelitian ini adalah kemandirian belajar mahasiswa dan opini mereka dalam mengikuti pembelajaran dalam jaringan.

Subjek dalam penelitian ini adalah 85 orang mahasiswa yang mengambil Mata Kuliah Matematika Dasar pada TA 2020/2021. Data dikumpulkan dengan menggunakan kuisioner yang diadaptasi dari Onah dan Sinclair (2017) skala 1-5. Data kemudian dianalisis menggunakan analisis statistic setelah dibuat kode dan dibagi menjadi 2 kategori yaitu Tinggi (jika rata-rata lebih dari 3.5) dan Rendah (jika rata-rata kurang dari 3.5). Kuisioner dibagikan setelah 6 pertemuan dilakukan dengan Pembelajaran Jarak Jauh. Selanjutnya peneliti melakukan wawancara tidak terstruktru untuk mengetahui opini mahasiswa terkait pembelajaran jarak jauh.

Informasi yang ingin diketahui peneliti adalah kemandirian belajar mahasiswa yang mengikuti pembelajaran dalam jaringan karena situasi Pandemi Covid-19 dengan disertai pendapat mereka terkait pembelajaran dalam jaringan ini.

Untuk mendapatkan data ini, peneliti menggunakan kuisioner Kemandirian Belajar kepada mahasiswa dengan menggunakan Google Form. Proses pengumpulan data dilakukan dengan menggunakan instrumen yang telah diadaptasi dari dikenal sebagai MOOC online self-regulated learning questionnaire (MOSLQ) yang biasa digunakan untuk mengukur kemandirian belajar (Onah \& Sinclair, 2017).

\section{Hasil dan Pembahasan}

Pembelajaran Matematika Dasar menggunakan Learning Management System (LMS) Unika Santu Paulus Ruteng yang dapat diakses melalui http://elearning.unikastpaulus.ac.id// seperti pada Gambar 1.

Secara umum, proses pembelajaran Matematika Dasar dilakukan dengan urutan sebagai berikut:

1. Dosen membagikan materi Perkuliahan sebelum perkuliahan dilangsungkan.

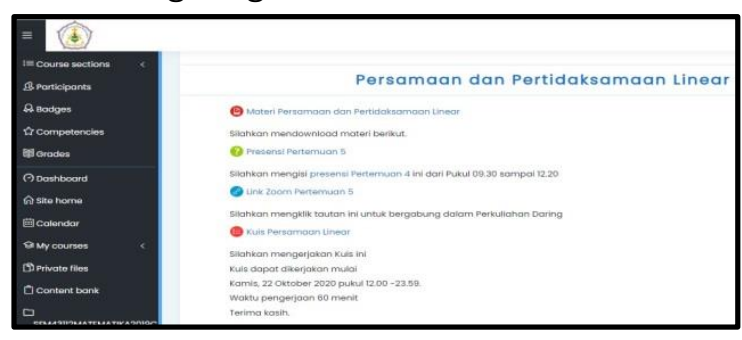

Gambar 1. Tampilan LMS Matematika Dasar

2. Pembahasan Materi dilakukan dengan menggunakan Video Conference Zoom

3. Kehadiran mahasiswa dipantau melalui LMS dan juga Zoom

4. Perkuliahan dilangsungkan dengan memanfaatkan fitur share screen baik untuk share materi maupun whiteboard. Penggunaan whiteboard dapat dimaksimalkan karena menggunakan pen-tablet.

5. Setelah perkuliahan selesai dilakukan, mahasiswa diberikan kesempatan untuk mengerjakan kuis tentang 
materi yang baru saja dipelajari. Kuis berupa pilihan ganda dan terdiri dari maksimal 10 soal. Soal kuis diacak dan diambil dari bank soal, mahasiswa diberi kesempatan untuk re-attempt kuis, dan akan diambil skor yang tertinggi.

Seperti yang telah dijelaskan pada bagian II, peneliti menggunakan instrumen yang telah diadaptasi dari dikenal sebagai MOOC online self-regulated learning questionnaire

(MOSLQ)

mengukur kemandirian belajar (Onah \& Sinclair, 2017). Instrumen ini terdiri dari 19 butir dengan skala 5 (sangat tidak setuju sampai sangat setuju) dan diedarkan dengan menggunakan Google Form. Indikator dalam kemandirian belajar yang dipakai adalah (1) Tujuan belajar, (2) Strategi belajar, (3) Managemen waktu, Lingkungan, (5) Pencarian bantuan, (6) Evaluasi diri.

Tabel 1.

Butir Kuisioner Kemandirian Belajar

\begin{tabular}{|c|c|c|}
\hline No & Indikator & Item Pernyataan \\
\hline 1 & Tujuan Belajar & Saya tahu apa yang akan saya capai dalam mata kuliah Matematika Dasar ini \\
\hline 2 & Tujuan Belajar & $\begin{array}{l}\text { Saya telah menyisihkan waktu untuk mempelajari mata kuliah Matematika } \\
\text { Dasar }\end{array}$ \\
\hline 3 & Tujuan Belajar & $\begin{array}{l}\text { Saya memiliki standar tinggi untuk tugas-tugas atau kuis saya dalam mata } \\
\text { kuliah Matematika Dasar ini }\end{array}$ \\
\hline 4 & Tujuan Belajar & $\begin{array}{l}\text { Saya telah menetapkan target untuk semua yang ingin saya capai dalam mata } \\
\text { kuliah Matematika Dasar ini }\end{array}$ \\
\hline 5 & Tujuan Belajar & $\begin{array}{l}\text { Saya tidak melihat keterlibatan saya dalam mata kuliah Matematika Dasar } \\
\text { tidak penting karena mata kuliah Matematika Dasar dilaksanakan secara } \\
\text { online }\end{array}$ \\
\hline 6 & Tujuan Belajar & $\begin{array}{l}\text { Saya telah menuliskan tujuan yang saya rencanakan untuk dicapai pada akhir } \\
\text { mata kuliah Matematika Dasar ini }\end{array}$ \\
\hline 7 & Strategi belajar & $\begin{array}{l}\text { Saya bekerja secara strategis untuk memprioritaskan tugas untuk membantu } \\
\text { saya mencapai tujuan pembelajaran saya }\end{array}$ \\
\hline 8 & Strategi belajar & $\begin{array}{l}\text { Saya mempersiapkan studi online saya dengan membaca materi } \\
\text { pembelajaran yang sudah diberikan sebelumnya }\end{array}$ \\
\hline 9 & Strategi belajar & $\begin{array}{l}\text { Saya menetapkan agenda studi saya sebelum mencari materi terkait yang } \\
\text { tersedia pada internet }\end{array}$ \\
\hline 10 & Strategi belajar & $\begin{array}{l}\text { Saya siap untuk menangani setiap aspek pekerjaan yang menantang dalam } \\
\text { mata kuliah Matematika Dasar ini }\end{array}$ \\
\hline 11 & $\begin{array}{l}\text { Managemen } \\
\text { waktu }\end{array}$ & $\begin{array}{l}\text { Saya telah merencanakan sebelumnya untuk mengalokasikan waktu yang } \\
\text { diperlukan untuk studi online saya }\end{array}$ \\
\hline 12 & $\begin{array}{l}\text { Managemen } \\
\text { waktu }\end{array}$ & $\begin{array}{l}\text { Saya menemukan waktu yang tepat untuk belajar agar saya tidak terganggu } \\
\text { dalam belajar }\end{array}$ \\
\hline 13 & Lingkungan & Saya memilih lokasi belajar yang nyaman untuk menghindari gangguan \\
\hline 14 & Lingkungan & Saya selalu mencari tempat yang nyaman untuk belajar \\
\hline 15 & Ling & ekerja agar dapat belajar secara \\
\hline
\end{tabular}




\begin{tabular}{|cll|}
\hline \multicolumn{1}{c}{} & \multicolumn{2}{l}{ efektif } \\
\hline 16 & $\begin{array}{l}\text { Pencarian } \\
\text { bantuan }\end{array}$ & $\begin{array}{l}\text { Saya berencana untuk menggunakan saluran komunikasi interaktif (Whatsapp } \\
\text { Group) yang disediakan untuk mendapatkan dukungan dari teman sekelas }\end{array}$ \\
\hline 17 & $\begin{array}{l}\text { Pencarian } \\
\text { bantuan }\end{array}$ & $\begin{array}{l}\text { Saya berencana untuk berpartisipasi dalam forum diskusi mata kuliah } \\
\text { Matematika Dasar untuk mendapatkan hasil maksimal }\end{array}$ \\
\hline 18 & Evaluasi diri & $\begin{array}{l}\text { Saat mengikuti mata kuliah Matematika Dasar ini, saya akan merefleksikan } \\
\text { studi saya di setiap topik bahasan }\end{array}$ \\
\hline 19 & Evaluasi diri & $\begin{array}{l}\text { Saya akan terlibat secara aktif untuk memantau perkembangan belajar yang } \\
\text { telah saya ikuti secara online. }\end{array}$ \\
\hline
\end{tabular}

Respon Mahasiswa untuk setiap pernyataan disajikan dalam Tabel 2.

Tabel 2.

\begin{tabular}{|c|c|c|c|c|c|}
\hline \multicolumn{6}{|c|}{ Respon Mahasiswa } \\
\hline \multirow[t]{2}{*}{ Kategori } & \multicolumn{5}{|c|}{ \% respon mahasiswa } \\
\hline & 1 & 2 & 3 & 4 & 5 \\
\hline $\begin{array}{l}\text { Tujuan } \\
\text { Belajar }\end{array}$ & 8.8 & 7.6 & 13.1 & 20.4 & $\begin{array}{c}50 . \\
1\end{array}$ \\
\hline $\begin{array}{l}\text { Strategi } \\
\text { Belajar }\end{array}$ & 3.5 & 10.0 & 11.8 & 20.0 & $\begin{array}{c}54 . \\
7\end{array}$ \\
\hline $\begin{array}{l}\text { Managemen } \\
\text { waktu }\end{array}$ & 4.1 & 4.1 & 11.2 & 20.6 & 60 \\
\hline Lingkungan & 2.4 & 2.7 & 7.8 & 19.2 & $\begin{array}{c}67 . \\
9\end{array}$ \\
\hline $\begin{array}{l}\text { Pencarian } \\
\text { bantuan }\end{array}$ & 4.1 & 2.4 & 10.6 & 18.8 & $\begin{array}{c}64 . \\
1\end{array}$ \\
\hline Evaluasi Diri & 2.9 & 12.9 & 24.1 & 55.9 & 4.2 \\
\hline $\begin{array}{l}\text { Selanjut } \\
\text { mahasiswa } \\
\text { belajar di } \\
\text { rata-rata k } \\
\text { dikategorik } \\
\text { kemandiria } \\
\text { mahasiswa } \\
\text { bawah a } \\
\text { dikategorik } \\
\text { kemandiria }\end{array}$ & $\begin{array}{l}\text { ya, } p \\
\text { be } \\
\text { tana } \\
\text { man } \\
\text { n se } \\
\text { be } \\
\text { deng } \\
\text { au } \\
\text { n se }\end{array}$ & $\begin{array}{l}\text { neliti } \\
\text { dasar } \\
\text { jika } \\
\text { rian } \\
\text { agai } \\
\text { ajar } \\
\text { ken } \\
\text { sama } \\
\text { agai } \\
\text { ar ren }\end{array}$ & $\begin{array}{l}\text { nengk } \\
\mathrm{n} \quad \mathrm{k} \\
\text { ahasis } \\
\text { lajar } \\
\text { ahasis } \\
\text { nggi } \\
\text { ndiria } \\
\text { den } \\
\text { ahasis } \\
\text { ah. }\end{array}$ & $\begin{array}{l}\text { sifikas } \\
\text { mand } \\
\text { va der } \\
\text { atas } \\
\text { va der } \\
\text { sedan } \\
\text { belaj } \\
\text { an } \\
\text { va der }\end{array}$ & $\begin{array}{l}\text { ikan } \\
\text { irian } \\
\text { ngan } \\
3.50 \\
\text { ngan } \\
\text { gkan } \\
\text { ar di } \\
3.50 \\
\text { ngan }\end{array}$ \\
\hline
\end{tabular}

Tabel 3.

Kategori Kemandirian Belajar

\begin{tabular}{|c|c|c|c|c|c|}
\hline \multirow{3}{*}{$\begin{array}{l}\mathrm{N} \\
\mathrm{O}\end{array}$} & \multirow[t]{3}{*}{ INDIKATOR } & \multicolumn{4}{|c|}{ KATEGORI } \\
\hline & & \multicolumn{2}{|c|}{ TINGGI } & \multicolumn{2}{|c|}{ RENDAH } \\
\hline & & $f$ & $\%$ & $f$ & $\%$ \\
\hline 1 & Tujuan Belajar & 65 & 76.47 & 16 & 23.53 \\
\hline 2 & $\begin{array}{l}\text { Strategi } \\
\text { Belajar }\end{array}$ & 65 & 76.47 & 20 & 23.53 \\
\hline 3 & $\begin{array}{l}\text { Managemen } \\
\text { Waktu }\end{array}$ & 63 & 74.12 & 20 & 25.88 \\
\hline 4 & Lingkungan & 74 & 87.06 & 22 & 12.94 \\
\hline 5 & $\begin{array}{l}\text { Pencarian } \\
\text { Bantuan }\end{array}$ & 68 & 80.00 & 11 & 20.00 \\
\hline 6 & Evaluasi Diri & 62 & 72.94 & 17 & 27.06 \\
\hline & $\begin{array}{l}\text { Rata-Rata } \\
\text { Umum }\end{array}$ & 69 & 81.18 & 23 & 18.82 \\
\hline
\end{tabular}

\section{A. Kemandirian Belajar Mahasiswa}

Daftar pertanyaan kuisioner terkait kemandirian belajar diadaptasi dari penelitian yang dilakukan Onah dan Sinclair (2017). Kemandirian belajar mengacu pada perilaku dan kemauan dari pembelajar individu untuk berhasil dalam pembelajaran yang diikuti (Onah \& Sinclair, 2017). Perilaku tersebut termasuk tetapi tidak terbatas pada hal-hal berikut: menetapkan tujuan studi (penetapan tujuan), menyusun strategi cara yang 
efektif untuk menyelesaikan tugas yang diberikan (strategi tugas), merencanakan waktu belajar yang efektif (manajemen waktu), memutuskan lokasi studi yang akan diperoleh manfaat optimal dengan gangguan rendah (penataan lingkungan), meminta bantuan dari teman sebaya dan tutor dalam memberikan bantuan di bidang yang menjadi perhatian (mencari bantuan) dan terakhir refleksi diri pada studi pribadi untuk mengevaluasi tujuan yang dicapai (evaluasi diri) (Onah \& Sinclair, 2017).

Berdasarkan hasil penelitian yang dilakukan sebanyak $76.47 \%$ mahasiswa sudah menetapkan tujuan dalam pembelajaran meskipun pembelajaran dilakukan dalam jaringan. Mahasiswa mengetahui apa yang ingin dicapai dan menetapkan target selama proses pembelajaran sehingga mereka menyediakan waktu untuk mempelajari Mata Kuliah Matematika Dasar. Meskipun demikian masih ada 23.53 \% yang belum menetapkan tujuan belajarnya.

Selain itu, sebanyak $76.47 \%$ mahasiswa melakukan strategi tertentu untuk mencapai tujuan belajar. Sikap-sikap itu ditunjukkan di antaranya dengan mengerjakan tugas, mempersiapkan diri sebelum perkuliahan, dan mencari sumber-sumber belajar lain dari internet. Namun, 23.53\% mahasiswa memiliki kemandirian belajar yang rendah dikarenakan tidak adanya strategi dalam mengikuti pembelajaran dalam jaringan ini. Kemandirian belajar mahasiswa terlatih dengan baik saat penerapan pembelajaran jarak jauh. Mahasiswa terbiasa mencari jawaban dari pertanyaan dengan mencari jawaban pada internet.

Salah satu indicator kemandirian belajar adalah managemen waktu. Sebanyak 74.12\% mahasiswa mengalokasikan waktu khusus untuk belajar dan mengerjakan tugas-tugas yang diberikan melalui Moodle. Dengan adanya hal ini, kemampuan lain yang muncul adalah kemampuan untuk memilah informasi yang bertebaran di dunia maya sebagai jawaban dari pertanyaan yang diajukan baik itu terkait materi pembelajaran maupun tugas-tugas yang diberikan. Meski demikian, 25.88\% mahasiswa tidak mengalokasikan waktunya untuk belajar dan mengerjakan tugas-tugas yang diberikan.

Selanjutnya, sebagian besar mahasiswa (87.06\%) mencari lingkungan dan kondisi yang memadai untuk menunjang proses pembelajaran misalkan dengan mencari tempat dengan sinyal internet yang mendukung serta tidak terlalu ramai. Selain itu, mapir semua mahasiswa yaitu sekitar 80\% mahasiswa juga secara menggunakan WAG dan Forus Diskusi pada Moodle untuk mendapatkan informasi yang dibutuhkan baik terkait materi yang belum dipahami maupun tugas-tugas yang telah diberikan. Namun, penelitian menunjukkan bahwa hanya 72.94\% mahasiswa yang melakukan evaluasi dan refleksi terhadap hasil belajar yang telah dicapai, meskipun hasil belajar 
dapat dengan mudah diakses pada Moodle.

\section{B. Pendapat Mahasiswa terkait Pembelajaran Jarak Jauh}

Seperti yang telah diketahui beberapa penelitian telah dilakukan terkait proses pendidikan jarak jauh. Selain melihat ketercapaian perkembangan kognitif dari mahasiswa, perlu diperhatikan pandangan mahasiswa terkait Mata Kuliah yang ditempuh dalam hal ini untuk melihat perkembangan afektif mereka. Untuk itu, penelitian ini bertujuan untuk mengetahui pandangan mahasiswa yang mengambil mata kuliah Matematika Dasar Tahun Akademik 2020/2021. Aspek-aspek yang dilihat adalah: apa saja kesulitan yang dialami selama proses pembelajaran dalam jaringan karena situasi Pandemi Covid-19 ini, apa saja manfaat atau potensi atau kelebihan dari pembelajaran jarak jauh ke depannya, apa kekurangan dari pembelajaran jarak jauh yang telah diterapkan, dan seberapa memadai infrastruktur teknologi yang dimiliki universitas untuk mengoptimalkan masa transisi pembelajaran dalam jaringan selama masa darurat Pandemi Covid-19.

Kesulitan yang dialami mahasiswa terutama dikarenakan transformasi yang sangat drastic dalam proses pembelajaran. Berdasarkan wawancara semi-terstruktur yang dilakukan mahasiswa mengeluhkan bahwa mereka tidak suka pembelajaran yang tidak berlangsung di kelas terutama saat awal-awal perkuliahan. Mereka kesulitan untuk belajar tanpa didukung suasana belajar seperti yang biasa mereka alami. Mahasiswa terbiasa belajar di kelas dengan dikelilingi teman-teman dan juga dosen. Suasana akademik sangat mendukung untuk proses pembelajaran. Tetapi pandemic memaksa mereka untuk belajar dari rumah dengan situasi belajar yang kadang kurang mendukung. Namun seiring berjalannya waktu, mahasiswa mulai berdamai dengan keadaan pembelajaran jarak jauh dan mulai menyesuaikan diri agar hasil belajar bisa lebih maksimal. Ini didukung dengan hasil penelitian yang menunjukkan bahwa lebih dari $70 \%$ mahasiswa menciptakan lingkungan yang mendukung situasi belajar dan memanagemen waktunya untuk belajar.

Manfaat dan potensi pembelajaran jarak jauh terlihat dari keinginan mahasiswa untuk mencari materi pembelajaran lain, mahasiswa tidak merasa bahwa keterlibatan dalam mata kuliah Matematika Dasar kurang penting semata-mata karena mata kuliah Matematika Dasar dilaksanakan secara online justru mengalokasikan waktu, tenaga, dan pikiran yang diperlukan untuk mencapai standar yang ditetapkan. Namun, sejauh wawancara yang dilakukan mahasiswa tetap melihat pembelajaran jarak jauh sebagai opsi dikarenakan pembelajaran tatap muka tidak mungkin dilangsungkan. Mahasiswa tetap lebih menyukai pembelajaran tatap muka. Pembelajaran jarak jauh dijadikan sebagai pembelajaran penunjang bukan 
pembelajaran utama secara khusus untuk Mata Kuliah yang membutuhkan perhitungan-perhitungan matematis seperti Matematika Dasar.

Infrastruktur yang tersedia di Manggarai Raya yang mencakup 3 Kabupaten yaitu Kabupaten Manggarai, Kabupaten Manggarai Timur, dan Kabupaten Manggarai Barat belumlah merata. Masih ada mahasiswa yang kesulitan untuk mengakses internet dari rumah sehingga harus berpindah lokasi untuk mendapatkan sinyal Internet. Mahasiswa tidak mengalami kesulitan Kuota Belajar karena adanya Subsidi Kuota Belajar dari Kementrian Pendidikan dan Kebudayaan. Selain itu, sinyal internet juga kurang stabil sehingga terkadang menyulitkan proses pembelajaran. Selain hal teknis ini, mahasiswa juga kesulitan karena curah hujan yang tinggi. Terlepas dari keterbatasan infrakstruktur ini, lebih dari 80\% mahasiswa berupaya untuk mencari lingkungan yang dapat menunjang pembelajaran. Dosen dan mahasiswa juga menjalin komunikasi yang intens terkait waktu pembelajaran yang tepat jika cuaca tidak mendukung proses pembelajaran.

\section{Pembahasan}

Pembelajaran jaringan jarak jauh tidak hanya mengubah strategi belajarmengajar, tetapi juga memberikan kemungkinan-kemungkinan baru untuk meningkatkan target-target dalam dunia akademis (Chyr et al., 2017). Pembelajaran jarak jauh berpotensi meningkatkan kemandirian belajar yang dapat dilihat dari penentuan tujuan belajar, strategi belajar, managemen waktu, lingkungan, pencarian bantuan, dan evaluasi diri. Penelitian terdahulu menunjukkan bahwa kemandirian belajar dapat meningkatkan prestasi dan hasil afektif yang diinginkan (Abdul \& Kurukkan, 2016; Endedijk et al., 2016; Afriansyah \& Dahlan, 2017; González-Torres \& Torrano, 2008; Asih \& Ramdhani, 2019). Dijelaskan bahwa kemandirian belajar bermanfaat tidak hanya untuk kinerja akademik, tetapi juga untuk pengembangan keahlian dalam karir profesional.

Hasil paling menarik dari penelitian ini adalah kemandirian belajar mahasiswa terlatih dengan baik saat penerapan pembelajaran jarak jauh. Ini terlihat dari lebih dari 75\% mahasiswa menetapkan stategi belajar untuk mencapai tujuan belajar yang diinginkan. Selain itu, lebih dari 80\% mahasiswa membiasakan diri mencari jawaban dari tugas-tugas pada internet.

Mahasiswa dipersiapkan lebih awal untuk menghadapi "dunia nyata" dimana pengaturan target pembelajaran, penyesuaian strategi dalam proses pembelajaran, penyediaan sumber daya untuk mengoptimalkan hasil belajar, kolaborasi dalam belajar di luar kelas, dan evaluasi dalam proses pembelajaran dapat diaplikasikan saat menyelesaikan pendidikan nantinya. 


\section{Penutup}

Selama mengikuti pembelajaran dalam jaringan karena adanya Pandemi Covid-19 mahasiswa mengalami kesulitan dalam beradaptasi perubahan kebiasaan belajar, keterbatasan sumber daya belajar dalam jaringan, dan kurangnya interaksi baik sesama mahasiswa maupun dengan dosen.

Namun keterbatasan ini mendorong mahasiswa semakin mandiri dalam belajar yang terlihat dari lebih dari $70 \%$ mahasiswa sudah menetapkan tujuan belajar, strategi belajar, mampu mengatur waktu belajar, dan melakukan evaluasi diri terhadap proses pembelajaran yang telah diikuti. Lebih lanjut, lebih dari $80 \%$ mahasiswa menentukan lingkungan belajar yang mendukung suasana belajar dan mencari bantuan dari rekan sekelas apabila mengalami kesulitan dalam belajar.

Berdasarkan hasil penelitian ini, kampus diharapkan lebih mempersiapkan kebijakan terkait Proses Pembelajaran Jarak Jauh sehingga dosen dan mahasiswa dapat tetap melaksanakan perkuliahan secara efektif dan tetap menumbuhkan kemandirian belajar bagi mahasiswa.

\section{UCAPAN TERIMA KASIH}

Penulis mengucapkan terima kasih kepada Lembaga Penelitian dan Pengabdian Kepada Masyarakat Universitas Katolik Indonesia Santu Paulus
Ruteng yang berkenan mendukung terlaksananya penelitian ini.

\section{DAFTAR PUSTAKa}

Abdul, G., \& Kurukkan, A. (2016). SelfRegulated Learning: A Motivational Approach for Learning Mathematics. International Journal of Education and Psychological Research, 5(3), 6065.

Afriansyah, E. A., \& Dahlan, J. A. (2017, May). Design Research in Fraction for Prospective Teachers. In 5th SEA-DR (South East Asia Development Research) International Conference 2017 (SEADRIC 2017) (pp. 91-97). Atlantis Press.

Afriansyah, E. A., Sofyan, D., Puspitasasri, N., Lurytawati, I. P., Sundayana, R., Maryati, I., Noordyan, M. A., \& Basuki, B. (2020). Edmodo E-learning Media Training for Learning Optimization. Jurnal Pekemas, 3(2), 33-39.

Asih, N., \& Ramdhani, S. (2019). Peningkatan Kemampuan Pemecahan Masalah Matematis dan Kemandirian Belajar Siswa Menggunakan Model Pembelajaran Means End Analysis. Mosharafa: Jurnal Pendidikan Matematika, 8(3), 435446.

Assagaf, G. (2017). The Influence of Independent Learning and Self Regulation Toward Learning Result of Mathematics Subject Through Achievement Motivation of Grade X Students at SMAN in Ambon. Jurnal Daya Matematis, 5(2), 117-123.

Chyr, W., Shen, P., Chiang, Y., Lin, J., \& Tsai, C. (2017). Exploring the Effects 
of Online Academic Help-Seeking and Flipped Learning on Improving Students ' Learning. Educational Technology \& Society, 20(3), 11-23.

Dilmaç, S. (2020). Students' Opinions about the Distance Education to Art and Design Courses in the Pandemic Process. World Journal of Education, 10(3), 113.

Endedijk, M. D., Brekelmans, M., Sleegers, P., \& Vermunt, J. D. (2016). Measuring students' self-regulated learning in professional education: bridging the gap between event and aptitude measurements. Quality and Quantity, 50(5), 2141-2164.

Erin, E., \& Maharani, A. (2018). Persepsi Mahasiswa Pendidikan Matematika terhadap Perkuliahan Online. Mosharafa: Jurnal Pendidikan Matematika, 7(3), 337-344.

Foster, F. L., \& Cresap, L. (2012). Using Reasoning Tasks to Develop Skills Necessary to Learn Independently. Minot State University.

González-Torres, M.-C., \& Torrano, F. (2008). Methods and Instrumens for Measuring Self-regulated Learning. In Handbook of Instructional Resources \& Applications (Issue January 2008, pp. 1-19).

Gross, B., \& Opalka, A. (2020). Too Many Schools Leave Learning to Chance During the Pandemic. In Center on Reinventing Public Education (Issue June).

Mulyono, D. (2017). The influence of learning model and learning independence on mathematics learning outcomes by controlling students ' early ability. International Electronic Journal of Mathematics
Education, 12(3), 689-708.

Nurhikmayati, I., \& Sunendar, A. (2020). Pengembangan Project Based Learning Berbasis Kearifan Lokal Berorientasi pada Kemampuan Berpikir Kreatif dan Kemandirian Belajar. Mosharafa: Jurnal Pendidikan Matematika, 9(1), 1-12.

Onah, D. F. O., \& Sinclair, J. E. (2017). Assessing Self-Regulation of Learning Dimensions in a Stand-alone MOOC Platform. International Journal of Engineering Pedagogy (IJEP), 7(2), 4.

Pratiwi, C., Neviyarni, N., \& Solfema, S. (2018). Contribution self efficacy and independent learning math toward students' mathematics learning outcomes. International Conferences on Educational, Social Sciences, and Technology, March 2017, 674-678.

Robiana, A., \& Handoko, H. (2020). Pengaruh Penerapan Media UnoMath untuk Meningkatkan Kemampuan Komunikasi Matematis dan Kemandirian Belajar Siswa. Mosharafa: Jurnal Pendidikan Matematika, 9(3), 521-532.

Sundayana, R. (2019). Perbandingan Desain Pembelajaran ASSURE dan PPSI untuk Meningkatkan Kemampuan Pemecahan Masalah Matematis dan Kemandirian Belajar. Mosharafa: Jurnal Pendidikan Matematika, 8(1), 143-154.

Tezer, M., Yildiz, E. P., Bozkurt, S., \& Tangul, H. (2019). The influence of online mathematics learning on prospective teachers mathematics achievement: The role of independent and collaborative learning. World Journal on Educational Technology: Current 
Issues, 11(4), 257-265.

Yilmaz, A. B., \& Banyard, P. (2020). Engagement in Distance Education Settings: A Trend Analysis. Turkish Online Journal of Distance Education, 21(1), 101-120.

\section{Riwayat Hidup PenUlis}

\section{Emilianus Jehadus, S.S., M.Pd.}

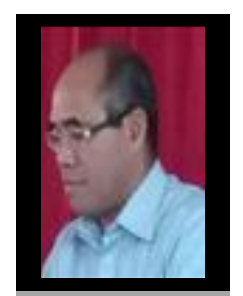

Lahir di Malawatar, 21 Mei 1969. Staf pengajar di Universitas Katolik Indonesia Santu Paulus Ruteng. S1 di FKIP Universitas Sanata Dharma pada tahun 2012. S2 Pendidikan Matematika diperoleh dari Universitas Negeri Surabaya tahu 2017.

\section{Alberta Parinters Makur, S.Si, M.Pd.}

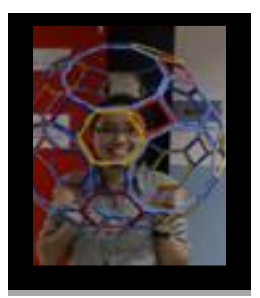

Lahir di Ende, 9 Mei 1988. Staf pengajar di Program Studi Pendidikan Matematika Unika Santu Paulus Ruteng. Studi S1 Matematika Universitas Indonesia, Depok, lulus tahun 2009 dan S2 Pendidikan Matematika Universitas Negeri Jakarta, lulus tahun 2014.

\section{Sebastianus Fedi, M.Pd.}

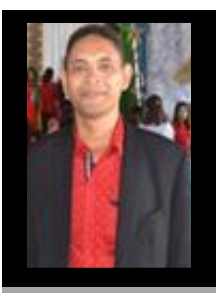

Lahir di Heso, 27 Desember 1979. Staf pengajar di Unika Santu Paulus Ruteng. S1 Program Studi Matematika di Universitas Nusa Cendana pada tahun 2006. S2 Pendidikan Matematika di UNDIKSHA Singaraja tahun 2014.

\section{Silfanus Jelatu, M.Pd.}

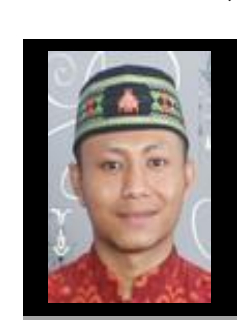

Lahir di Mukun (Kab. Manggarai Timur, NTT), pada tanggal 4 Mei 1992. Staf pengajar di Program Studi Pendidikan Matematika Unika Santu Paulus Ruteng. S1 di bidang Pendidikan matematika
Universitas Flores, Ende-NTT, Iulus tahun 2014; S2 di Bidang Pendidikan Matematika Universitas Pendidikan Ganesha, Singaraja-Bali, lulus tahun 2017.

Viviana Murni, M.Pd.

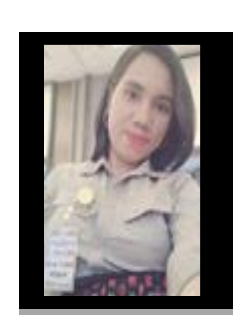

Lahir di Marang, 08 September 1991. Staf Pengajar di Program Studi Pendidikan Matematika Universitas Katolik Indonesia Santu Paulus Ruteng. S1 Pendidikan Matematika Universitas Flores, Ende, lulus tahun 2014; dan S2 Pendidikan Matematika Universitas Pendidikan Ganesha, Iulus tahun 2017.

\section{Polikarpus Raga, M.Th.}

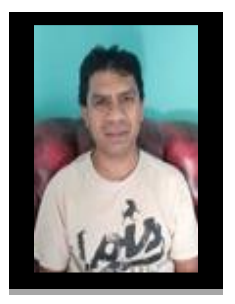

Lahir di Pauleka, 28 Oktober 1976. Staf pengajar di program studi pendidikan matematika, Unika Santu Paulus Ruteng. S2 dalam bidang teologi Katolik di Sankt Philosoph-Und Theologische Hochschule Sankt Augustin-Bonn, Jerman. 